Information for citation:

Tikhonravov E. Yu. Printsip nullum crimen sine lege v istorii otechestvennogo ugolovnogo prava [Principle Nullum Crimen Sine Lege in the History of Russian Criminal Law]. Vestnik Permskogo Universiteta. Juridicheskie Nauki - Perm University Herald. Juridical Sciences. 2017. Issue 38. Pp. 548-557. (In Russ.). DOI: 10.17072/19954190-2017-38-548-557.

UDC 340: 341.4

DOI: 10.17072/1995-4190-2017-38-548-557

\title{
PRINCIPLE NULLUM CRIMEN SINE LEGE IN THE HISTORY OF RUSSIAN CRIMINAL LAW
}

This study is supported by the grant of the President of the Russian Federation for the state support of young Russian scholars No. MK-6969.2016.6.

\section{E. Yu. Tikhonravov}

Siberian Federal University

79, Svobodny prospekt, Krasnoyarsk, 660041, Russia

ORCID: 0000-0003-2132-842X

ResearcherID: S-6967-2016

e-mail: etikhonravov@sfu-kras.ru

Introduction: the principle nullum crimen sine lege was applied by the courts of the Russian Empire and of the USSR in the light of the competition of two interests. The first one, which this principle aims to safeguard, is ensuring of personal freedom - an opportunity to do everything which is not prohibited by the law. The second one is the need to prevent harmful acts which the legislature failed to foresee and criminalize in advance. Purpose: to conduct historical and theoretical research into the application of the principle nullum crimen sine lege in Russian criminal law; based on the research, to draw conclusions which would be beneficial and important for the contemporary legal practice. Methods: the methodological framework of the research is based on general scientific methods (analysis, synthesis, deduction, induction, comparison, system approach, historical and statistical methods) and specific scientific methods (legal dogmatic, legal comparative, legal historical). Results: both interests - ensuring of personal freedom and the need to prevent harmful acts which the legislature failed to foresee and criminalize in advance - should find their implementation in judicial practice. It is argued that exactly this approach secures the survival and progress of the body politic. The article provides a method to determine lawful but nevertheless harmful acts which should be prevented by judges by means of reaching guilty verdicts, notwithstanding the legally binding principle nullum crimen sine lege. Conclusions: the findings of the paper suggest that due to the need to prevent harmful acts which the legislature failed to foresee and criminalize in advance, the principle nullum crimen sine would not be followed by judges on all occasions.

Keywords: nullum crimen sine lege; personal freedom; gaps in the law; analogia legis

(C) Tikhonravov E. Yu., 2017 


\title{
Information in Russian ПРИНЦИП NULLUM CRIMEN SINE LEGE В ИСТОРИИ ОТЕЧЕСТВЕННОГО УГОЛОВНОГО ПРАВА
}

\author{
Статья выполнена в рамках проведения научного исследования по гранту Президента РФ \\ для государственной поддержки молодых российских ученых - кандидатов наук № МК-6969.2016.6
}

\section{Е. Ю. Тихонравов}

Кандидат юридических наук, доцент кафедры теории и истории государства и права Юридический институт Сибирского федерального университета

660041, Россия, г. Красноярск, просп. Свободный, 79

ORCID: 0000-0003-2132-842X

ResearcherID: S-6967-2016

e-mail: etikhonravov@sfu-kras.ru

Введение: реализация приничип nullum crimen sine lege - «нет преступления без указания о нем в законе»-осуществлялась судами Российской империи и СССР в условиях конкуренции двух противоречащих друг другу общегосударственных интересов. Первый из них заключается в обеспечении неприкосновенности гражданской свободы - возможности делать все, что не запрещено законом. Второй состоит в пресечении вредньх для государства деяний, которые законодатель не предвидел и не воспретил посредством уголовноправовых норм заранее. Цель: выполнить исторический и теоретический анализ реализаиции принциипа пullum crimen sine lege в отечественном уголовном праве; сформулировать выводы, имеющие значение для современной юридической практики. Методы: методологическую основу исследования составили общенаучные средства познания: анализ, синтез, дедукиия, индукция, сравнение, системный подход, исторический и статистический методы; также применялись частнонаучные приемы изучения: юридико-догматический, сравнительно-правовой и историко-юридический методы. Результаты: в судебной деятельности требуется совмещать общегосударственные интересы обеспечения неприкосновенности гражданской свободы и пресечения вредных для государства деяний, которые законодатель не смог предвидеть заранее и поэтому учесть в праве. Сформулирована аргументация, согласно которой именно это сочетание отвечает изели самосохранения и прогресса государства. Предложен метод определения правомерных вредоносных деяний, которые в условиях юридического закрепления принципа пullum crimen sine lege должны подлежать пресечению судами. Выводы: принцип nullum crimen sine lege в будущем ради общегосударственных интересов будет реализовываться судами не во всех случаях.

Ключевые слова: nullum crimen sine lege; гражданская свобода; пробел в праве; аналогия закона

\section{Introduction}

As multiple studies indicate, judicial practice of various countries is characterized by the conflict of two competing interests $[21$, p. $226 ; 30$, pp. 71 , 77; 33, pp. 850-853; 35, pp. 33-34; 38, pp. 90-98, 264-268]. The first one, safeguarded by the principle nullum crimen sine lege, is personal freedom "an opportunity to do everything not prohibited by the law" [17, p. 70]. The second one is the prevention of harmful acts which the legislature failed to foresee and to criminalize in advance.

This conflict is also characteristic of Russia. The present paper demonstrates its existence in the judicial practice of the Russian Empire and then of the USSR. Next, the article provides a theoretical analysis of nullum crimen sine lege. The essay ends by presenting results and conclusions of the study.

Nullum Crimen Sine Lege in Criminal Law of the Russian Empire
The principle of nullum crimen sine lege was first incorporated in Russian criminal law in the $19^{\text {th }}$ century. Article 1 of the $15^{\text {th }}$ Volume of the 1832 Digest of Laws of the Russian Empire states, "Each act prohibited by the law under the threat of punishment is a crime" [18, p. 56].

Analogous provision was embodied in the 1845 Code of Criminal and Penitentiary Punishments. Its Article 4 defines crime as "an unlawful act itself or omission of what is prescribed under the threat of punishment by criminal or penitentiary law" [15, p. 174].

The principle of nullum crimen sine lege was also enshrined in Article 771 of the 1864 Code of Criminal Procedure. It specifies that "a court acquits the defendant if an act he was charged with is not prohibited under the threat of punishment by the law" [16, p. 446].

Having analyzed these articles, P. P. Pustoroslev came to the following conclusion: "In our 
criminal law, the sound general principle is adopted that those acts are criminal which have been declared criminal by the law" [14, p. 413]. This opinion was also subscribed to by many other Russian lawyers of that time: N. A. Butskovskij, A. D. Gradovskij, F. P. Dubrovin and N. S. Tagantsev [1, p. 33; 2, pp. 30-31; 5, pp. 20-21; 18, p. 191].

Some argue that nullum crimen sine lege existed in Russian criminal law before the $19^{\text {th }}$ century. For instance, drafters of the 1845 Code of Criminal and Penitentiary Punishments asserted that "since the enactment of the 1649 Sobornoye Ulozheniye, our legislation, as it is evident from the spirit of its provisions, recognized as crimes only those acts which were prohibited under the threat of punishment by the law" [1, p. 30].

This seems to be contentious. According to a widely shared opinion, in Continental Europe the principle of nullum crimen sine lege first found its legislative incorporation in the Penal Code of Austria [23, p. $30 ; 24$, p. $168 ; 36$, p. 77]. Its $\S 1$ ensures that "only those illegal acts are to be considered and treated as crimes which have been declared to be such by the present law" [27, p. 208]. As to the Latin formula nullum crimen sine lege, it was proposed by P. J. A. Feuerbach at the beginning of the $19^{\text {th }}$ century [22, p. 41].

The courts of the Russian Empire regularly ignored nullum crimen sine lege. In particular, individuals who committed lawful, yet harmful acts were often held criminally liable.

For instance, N. S. Tagantsev pointed out that "the cassational department of the [Governing] Senate [the Supreme Court of the Russian Empire] almost from the very beginning of its functioning developed a doctrine of its unrestricted power to fill any gap in the law" [18, p. 188]. Indeed, in 1868, the Governing Senate ruled that "an act, though not prohibited by any article of the law, can be punished if the acceptance of this act may lead to serious abuse" [5, pp. 29-30].

In order to fill gaps in the law, the courts of the Russian Empire frequently resorted to analogy. In 1906, the Governing Senate noted that "in order to apply criminal law by analogy, the following prerequisites are required: 1) unquestionable criminal nature of the act, 2) absence of penal law directly applicable to it, and 3) close similarity between this act and an action prohibited by criminal law" [11, p. 205].

One of the examples of application of criminal law by analogy was provided by P. P. Pustoroslev. 19-century Russian criminal law made no mention of blackmail. Despite this fact, "courts under the leadership of the Cassational Department [of the Governing Senate], finding some similarities between blackmail and fraud, extended provisions of criminal law regarding the latter to the former, and thereby by means of unlawful analogy transformed blackmail into a criminal act, imposing a punishment reserved for the fraud" [14, p. 18].

It is important to note that judges of the Russian Empire tried to maintain the illusion that the practice of filling gaps in criminal law was lawful. To this end, in their gap-filling rulings they often cited Article 12 of the 1864 Code of Criminal Procedure and Article 155 of the 1845 Code of Criminal and Penitentiary Punishments $[2$, p. 26; 11, pp. 204-205; 18, p. 188].

The first article specifies that "all courts shall decide cases in accordance with the precise meaning of the existing law; in the event of insufficiency, obscurity and inconsistency of legal rules [...] they shall base their judgments upon general meaning of the law" [16, p. 368]. It is no accident that this article, by contrast to similar Article 9 of the 1864 Code of Civil Procedure, omits "silence of the law".

As N. S. Tagantsev indicated, insufficiency of criminal law means that "the law forbids a certain action, but its description is not complete and leaves out some of its characteristics" [18, p. 187].

Silence of the law, on the other hand, is "a total lack of legal norms forbidding a certain action under the threat of punishment" [18, p. 187]. In other words, it "implies lacunae caused either by a mere legislative mistake and oversight, or by the fact that a criminal act came into existence only after the criminal code's enactment, or by specific reasons of criminal law policy" [18, p. 187]. Therefore, Article 12 of the 1864 Code of Criminal 
Procedure did not enable conviction for acts which no statute forbade.

The same conclusion applies to Article 155 of the 1845 Code of Criminal and Penitentiary Punishments. It states, "If the law does not specify a punishment for a criminal act at issue, then the judge shall sentence the offender to one of the punishments designed for crimes most analogous in their relevance and kind with this criminal act; the judge, however, shall submit his ruling - without bringing it into force and in accordance with the settled procedure of subordination - to the Governing Senate for consideration" $[15$, p. 205]. In the 1866 and 1885 editions of the Code of Criminal and Disciplinary Punishments, this rule appeared under Article 151.

The necessity of the said article is easy to explain. The $15^{\text {th }}$ Volume of the 1832 Digest of Laws of the Russian Empire was an incorporation of penal laws of previous centuries. One of their features was that sanctions were often phrased in the most general terms.

Due to this fact, the $15^{\text {th }}$ Volume of the 1832 Digest of Laws of the Russian Empire contained Article 104. It clarifies, "If the law determines the punishment in general terms, e.g. 'to punish the offender with all severity', or 'in accordance with the law', without specifying its class and its kind [...] then the court identifies the nature of the crime, compares it with similar and most analogous crimes and then imposes a punishment and submits the ruling to the higher judicial instance in accordance with the procedure of subordination" [5, p. 15].

The cited article does not enumerate all general terms used in the wording of penal sanctions. For example, some penal laws required "to punish the offender as one [i. e. the judge] pleases" $[2$, p. 14].

The 1845 Code of Criminal and Penitentiary Punishments also included rules with vaguely defined sanctions. This fact accounts for the existence of its Article 155, cited above.

These arguments are sufficient to establish that Article 155 of the 1845 Code of Criminal and Penitentiary Punishments did not enable conviction for acts which no statute forbade. As A. D. Gradovskij argued, this article "refers only to the case when the law failed to identify the precise punishment for a criminal act at issue. Consequently, this article leaves to the court's discretion determination of punishment, but does not authorize the court to criminalize an action omitted in legislation" [2, p. 28].

A. D. Gradovskij's analysis of Article 104 of the $15^{\text {th }}$ Volume of the 1832 Digest of Laws of the Russian Empire was almost identical. He asserted that "one cannot interpret it (as the current judicial practice nevertheless does) as the authorization to use analogy [...] one resorts to analogy when the law makes no provision for a certain act; in this case, however, the law provides for a certain act but does not determine a corresponding punishment" [2, p. 15]. This opinion was also held by many prerevolutionary legal scholars [5, pp. 16-18; 14, p. 18; 18, pp. 189-190].

\section{Nullum Crimen Sine Lege in Soviet Criminal Law}

From the very creation of the Soviet State, its courts enjoyed a wide discretion to fill gaps in the law. For instance, Article 22 of the 1918 Directive on People's Court of the RSFSR declares, "In deciding all disputes, the People's Court shall apply decrees enacted by the workers' and peasants' government; in the absence or insufficiency of a corresponding decree, the People's Court shall follow the socialist sense of justice." Analogous rules were expressed in Article 22 of the 1920 Directive on People's Court of the RSFSR. ${ }^{2}$

The issue of filling gaps in the law was discussed when drafting the 1922 Criminal Code of the RSFSR. At the third session of the ninth convocation of the All-Russian Central Executive Committee held in May 1922, People's Commissar of Justice D. I. Kurskii stated, "No criminal code is able to cover all diversity of criminal acts which de facto exist in society; if we are really willing to have a code which would fight acts dangerous for the regime, we should have articles enabling the court to employ analogy [...] The court would be empowered to intervene [in a certain case] and would not wait for the enactment of new legal rules" $[10$, p. 40$]$.

As a consequence, analogy found its way into the 1922 Criminal Code of the RSFSR. Pursuant to its Article 10, "When there is no direct reference to particular forms of crime in the Criminal Code,

\footnotetext{
${ }^{1}$ Polozhenie o narodnom sude RSFRS 1918 [Directive on People's Court of 1918], Sobranie uzakonenii RSFSR (1918) No. 85 item 889 .

2 Polozhenie o narodnom sude RSFRS 1920 [Directive on People's Court of 1920], Sobranie uzakonenii RSFSR (1920) No. 83 item 407.
} 
penalties or means of social protection shall be applied in accordance with Articles of the Criminal Code which deal with crimes most similar in their gravity and kind, and in conformity with the rules of the general part of the Code."

It was suggested that the use of analogy in Soviet criminal law would last for a short time. For instance, P. I. Liublinskii considered Article 10 of the 1922 Criminal Code of the RSFSR "as one of the provisions characteristic of the transitionary period of Soviet legislation" [10, pp. 49-50]. S. V. Poznyshev was of a similar opinion. He believed that this article, "triggered by the specific conditions of the present time, should be perceived as a temporary one" $[12$, p. 38].

These assumptions turned out to be false. The 1924 Basic Principles of the Criminal Legislation of the Union of SSR and Union Republics (Article 3 para. 3) and Criminal Codes of all Soviet Republics contained a provision for analogy. In particular, the analogy section was reenacted in the 1926 Criminal Code of the RSFSR. Its Article 16 states, "If a certain socially dangerous act is not directly provided for by the present Code, the basis and the scope of responsibility in respect thereof shall be determined in conformity with those Articles of the Code which deal with the crimes most closely resembling it." 2

In the late 1920s and in the 1930s, analogy received a widespread application in the Soviet judicial practice. For example, in 1939, a group of scholars determined that within 20 months, the courts of the Moscow region and the Moscow City Court had applied 53 provisions of the 1926 Criminal Code of the RSFSR (i.e. one third of all articles contained in the special part of the Code) in accordance with its Article 16 [12, p. 12]. These facts were also emphasized in academic publications abroad [37, p. 620].

The scholars argued that "this practice indicates an excessively widespread application of a

\footnotetext{
${ }^{1}$ Postanovlenie VTCIK ot 01.06 .1922 "O vvedenii v deistvie Ugolovnogo Kodeksa RSFSR (vmeste s Ugolovnym Kodeksom RSFSR)" [Decree of the All-Russian Central Executive Committee "On Bringing the Criminal Code of the RSFSR into Force (with the Criminal Code of the RSFSR)" issued on 01 June 1922], Sobranie uzakonenii RSFSR (1922) No. 15 item 153.

${ }^{2}$ Postanovlenie VTCIK ot 22.11.1926 "O vvedenii v deistvie Ugolovnogo Kodeksa RSFSR of 1926 (vmeste s Ugolovnym Kodeksom RSFSR)" [Decree of the All-Russian Central Executive Committee "On Bringing the Criminal Code of the RSFSR of 1926 into Force (with the Criminal Code of the RSFSR)" issued on 22 November 1926], Sobranie uzakonenii RSFSR (1926) No. 80 item 600.
}

great number of articles of the Code by analogy and in reality leads to the perversion of the instrument of analogy [...] Unrestricted use of analogy [...] is dangerous and politically harmful" [12, p. 12].

In 1938, editors of the Soviet Justice Journal came to similar conclusions. They confirmed that application of the analogy section "is occasionally coupled with the outrageous perversion of socialist criminal law" [8, p. 18]. For instance, articles of the penal code were often applied by analogy to acts already denounced in the code [8, p. 18].

Judgment of the Presidium of the Supreme Court of the RSFSR delivered on 17 March 1935 is one of the examples of this practice. It was ruled that "courts should intensify the suppression of hooliganism and imprison persistent hooligans. Exceptionally dangerous hooligans who commit single-handed assaults combined with a murder or armed resistance to authorities (involving violence, infliction of wounds etc.) shall be punished as bandits in conformity with Articles 16 and $59^{3}$ of the Code" [19, p. 60].

M. D. Shargorodsky criticized this decision and pointed out that the penal code "contains specific articles on murder, assault and resistance to authorities; this deprives the analogical application of law of any rationale". Aggravation of penalties, on the other hand, "can only be achieved through the legislative process, but not by means of judicial decisions" [19, p. 60].

There were other cases of inappropriate application of analogy in the Soviet jurisprudence. For instance, in 1934, the Supreme Court of the RSFSR ruled that "the reckless use of fire which led to the destruction of the property belonging to a collective farm is a socially dangerous action and shall be punished in conformity with Articles 16 and 79 [of the 1926 Criminal Code of the RSFSR]" [19, p. 60].

M. D. Shargorodsky commented on this decision in the following manner: "Article 79 deals only with deliberate destruction of property and in no way can be extended [by analogy] to reckless acts" $[19$, p. 60]. This view corresponded to the former position of the Supreme Court of the RSFSR. In 1926, it ruled that article of the penal code "which provides only for deliberate commission of a certain act cannot be applied through Article 10 (16) of the Criminal Code to cases where the same act was committed recklessly" [19, p. 60].

It is not surprising that in the 1930s the dispute amongst Soviet scholars over the use of analogy in criminal law began. A. A. Gertsenzon, I. T. Goljakov, 
M. M. Isaev, I. Romashkin, A. A. Piontkovskii demanded its abolition [7, p. 84; 8, p. 19]. Others held the opposite view. For instance, A. J. Vishinsky, resting on the cited arguments of D. I. Kurskii, stressed the need to further apply criminal law by analogy. This opinion was also held by M. D. Shargorodsky, who viewed analogy as "a useful instrument of fight" [19, p. 60].

The dispute, however, failed to bring considerable changes in the use of analogy in Soviet criminal law. Courts continued to employ the analogy article after World War II [6, p. 225], and this practice received approval of prominent legal scholars [6, pp. 220-226].

Nevertheless, in 1958, nullum crimen sine lege was reintroduced in Soviet criminal law. Article 7 of the 1958 Basic Principles of Criminal Legislation of the Union of the SSR and Union Republics defines crime as "a socially dangerous act or omission which is specified by criminal law and infringes the Soviet social and state order, social economic system, social property, the individual, political, labor, property and other rights of citizens as well as other socially dangerous acts against social legal order and specified by criminal law."

The said article, identifying the illegal nature of an act (in the phrase "specified by criminal law") as one of the attributes of criminal offense, was enacted in order to strengthen personal freedom [3, p. 82]. However, despite legislative adoption of nullum crimen sine lege, individuals were occasionally held to be criminally liable for lawful, yet socially harmful acts. It is worth emphasizing that in their decisions, judges made no mention both of gaps in the law and methods which they used to fill lacunae. Instead, courts declared that these acts fall under the articles of the penal code.

For example, P. S. Dagel reported that Soviet courts considered "joyriding as hooliganism and sale of stolen goods by a third person who did not promise the sale before the commission of the theft

\footnotetext{
${ }^{1}$ Zakon "Osnovy ugolovnogo zakonodatel'stva Soiuza SSR i soiuznykh respublik 1958 g." [Law "The Basic Principles of the Criminal Legislature of the USSR and Union Republics of 1958"], Vedomosi Verkhovnogo Soveta SSSR (1959) No. 1 item 6.
}

as complicity in the theft" $[3$, p. 86]. He maintained that these cases demonstrate convictions for acts not forbidden by criminal law and therefore constitute "incorrect and illegal application of analogy [...] made under the guise of legal interpretation" [3, p. 86].

It is hardly surprising that M. A. Kaufman arrived at the following conclusion. "Analogy was quite widely applied during all 36 years of its existence in Soviet criminal law. It did not cease to exist in practice after its formal repeal, gaining new forms which ably camouflaged its application" [9, p. 40].

I. Lapenna also noted that "the abolition of analogy, although salutary in principle, may not have such significant consequences" [28, p. 427]. He argued, "Political offenses - and also some others - are so widely defined [in the 1960 Criminal Code of the RSFSR] that these definitions provide a very elastic framework for covering all acts which are, or can be considered to be, dangerous for the regime" [28, p. 427]. Indeed, as B. Ackermann once noted, "If a judge has the possibility of embracing all cases of daily life through the concretization of the abstractly worded text of law, then there would be fewer offenses for which a judge would impose a justly deserved penalty exclusively by way of analogy and not by means of direct application of a legal rule" [20, p. 41].

\section{Theoretical Analysis of the Application of Nullum Crimen Sine Lege}

Historical facts concerning the principle nullum crimen sine lege in Russian criminal law require theoretical analysis. It should be noted at this point that both personal freedom and fight against lawful, yet socially harmful acts represent two conflicting interests, and normal functioning of the state requires that neither of them can be completely ignored.

Indeed, the courts' inability to fill gaps in criminal law dictated by the maxim nullum crimen sine lege might cause, among other negative consequences, even the state's collapse. It might be the case when legislators failed to foresee and prohibit 
socially harmful acts resulting, for instance, in mass deaths of people. In these circumstances, courts as governmental bodies first to be confronted with such dangerous acts would be unable to arrest them because they are not provided for by legal rules. Subsequent interference by the legislature could be too late to save the state.

Examining this issue, R. Jhering proposed the following course of action, which he considered one of the most important imperatives addressed to governmental bodies. "Exclusive domination of the law is synonymous with the resignation, on the part of society, of the free use of its hands. Society would give herself up with bound hands to rigid necessity, standing helpless in the presence of all circumstances and requirements of life which were not provided for in the law" [25, pp. 314-315]. However, "law exists for the sake of society, not society for the sake of law. Hence, it follows that when in exceptional cases [...] the relations are such that the government finds itself facing the alternatives of sacrificing either the law or society, it is not merely empowered but in duty bound to sacrifice law and save society. For higher than the law which it violates stands the consideration for the preservation of society, in the service of which all laws must stand" [25, p. 317].

J. Locke developed a similar point of view. He argued that "where the legislative and executive power are in distinct hands [...] there the good of the society requires that several things should be left to the discretion of him that has the executive power: for the legislators not being able to foresee, and provide by laws, for all that may be useful to the community, the executor of the laws having the power in his hands, has by the common law of nature a right to make use of it for the good of the society, in many cases, where the municipal law has given no direction $[\ldots]$ it is fit that the laws themselves should in some cases give way to the executive power, or rather to this fundamental law of nature and government, viz. That as much as may be all the members of the society are to be preserved: for since many accidents may happen, wherein a strict and rigid observation of the laws may do harm. [...] This power to act according to discretion, for the public good, without the prescription of the law, and sometimes even against it, is that which is called prerogative" [29, pp. 327-328].

\section{Results}

The above cited arguments of J. Locke and R. Jhering raise a question: in which cases should a judge violate the legally binding principle of nullum crimen sine lege and impose a penalty for an act not expressly declared criminal? The answer implies the comparison of the community benefit due to this act's prompt prevention with the harm inflicted by the breach of nullum crimen sine lege. If the former outweighs the latter, punishment should be deemed permissible. In the opposite case, a judge should acquit the defendant.

It seems that R. Zippelius used a similar line of reasoning. He argued that "judicial supplementation and correction of legislation" is permissible when "reasons" justifying this alteration "have more weight than the opposing principles of separation of powers and legal security" [39, p. 64]. The latter principle, in particular, means that "the judicial decisions are foreseeable to a certain extent, and therefore calculable enough that the individuals subject to the law can adapt their behavior to the foreseeable judicial decisions" [26, pp. 251-252].

Prevention of non-criminal, yet harmful acts ignoring the legally binding principle nullum crimen sine lege has to be legally justified. To this end, creative legal fiction can be employed. It is an assumption that conceals, or at least attempts to conceal, the fact that judges formulate and apply a legal ruling under the guise of applying a statutory rule to factual situations that cannot be logically subsumed under that rule [4, p. 23].

Creative legal fiction allows courts to achieve an important effect. Formulation and application of judicial rulings which cannot be derived from the existing law is perceived by citizens of the state as the lawful course of action.

Obviously, this has a positive influence on the efficiency of legal regulation: Citizens of the state would not follow the example set by its officials 
who ignore the existing law. As R. Pound asserted, "If the courts do not respect the law, who will?" [32, p. 123].

It is likely that judges of the Russian Empire and of the USSR at least partially realized the arguments presented in the previous and present sections of the paper and acted likewise. The historical facts regarding judicial application of the principle nullum crimen sine lege reported in this article seem to support this conclusion.

It is also worth noting that courts in many European countries perhaps have also taken into consideration these arguments. In 1925, E. Ehrlich pointed out that "analogy, for the most part, is removed from criminal law; however, it does not cease to exist in legal practice" [21, p. 226]. E. Rejewski [35, pp. 33-34], C.-W. Maris [30, pp. 71, 77] and S. Vogenauer [38, pp. 90-98, 264268] provided various cases where courts in Germany, France and in the Netherlands did not adhere to the legally binding maxim nullum crimen sine lege. In particular, S. Vogenauer asserted that "most of the judgments [...] explicitly or implicitly violating the prohibition of analogy were delivered between 1925 and 1979" [38, p. 92]. Furthermore, A. Mokhtar argued, "With regard to the principle nullum crimen sine lege, although it was recognized at this time as a general principle of criminal law and a principle of justice, the Tribunal [the Nuremberg Tribunals] diluted its rigidity" [31, pp. 52-53].

\section{Conclusions}

Historical and theoretical analysis of nullum crimen sine lege in Russian criminal law makes it possible to predict the future of this principle. It is suggested that nullum crimen sine lege would not always be strictly observed by the courts due to the need to prevent promptly the commission of noncriminal, yet harmful acts.

These are the main findings of the study on nullum crimen sine lege in the history of Russian criminal law. Some of them contrast sharply with viewpoints expressed in numerous legal publications. For instance, it has been stated that "in jurisprudence and legislation," the principle of nullum crimen sine lege "probably enjoys the highest recognition possible" [34, p. 155]. It is hoped that this paper may provoke a further discussion on $n u l$ lum crime sine lege.

\section{References}

1. Buckovskiy N. A. Ocherk kassatsionnogo poryadka otmeny resheniy po sudebnym ustavam 1864 goda [Essay on the Cassation Procedure of Reversal of a Judgment According to the 1864 Judicial Statutes]. St. Petersburg, 1866. 181 p. (In Russ.).

2. Gradovskiy A. D. O sudebnom tolkovanii zakonov po russkomu pravu [On the Judicial Interpretation of Laws According to the Russian Law]. Zhurnal grazhdanskogo $i$ ugolovnogo prava - Journal of Civil and Criminal Law. 1874. Issue 1. Pp. 1-62. (In Russ.).

3. Dagel' P. S. Ob analogii v sovetskom ugolovnom prave [On the Analogy According to Soviet Criminal Law]. Rossiyskiy kriminologicheskiy vzglyad - Russian Criminological Outlook. 2009. Issue 4. Pp. 82-86. (In Russ.).

4. Drobyshevskiy S. A., Tikhonravov E. Yu. Sposoby vospolneniya probelov $v$ prave [Methods of Filling Gaps in the Law]. Moscow, 2014. 176 p. (In Russ.).

5. Dubrovin F. P. O razmerakh dopustimosti analogii pri primenenii ugolovnogo zakona (okonchanie) [On the Scope of Admissibility of Analogy in Criminal Law Application (ending)]. Zhurnal ministerstva yustitsii - Journal of the Ministry of Justice. 1899. Issue 6. Pp. 1-35. (In Russ.).

6. Durmanov N. D. Ponyatie prestupleniya [The Notion of Crime]. Moscow, Leningrad, 1948. 315 p. (In Russ.).

7. Ioffe O. S. Otvetstvennost' po sovetskomu grazhdanskomu pravu [Responsibility According to Soviet Civil Law]. Leningrad, 1955. 310 p. (In Russ.).

8. K razrabotke proekta obshchey chasti Ugolovnogo kodeksa SSSR [On Drafting the General Part of the Criminal Code of the USSR]. Sovetskaya yustitsiya - Soviet Justice. 1938. Issue 20-21. Pp. 18-19. (In Russ.).

9. Kaufman M. A. Probely v ugolovnom prave $i$ sposoby ikh preodoleniya: avtoref. dis. ... d-ra yurid. nauk [Gaps in Criminal Law and Methods of Gap-Filling: Synopsis of Dr. jurid. sci. diss.]. Moscow, 2009. 51 p. (In Russ.).

10. Lyublinskiy P. I. Primenenie ugolovnogo zakona po analogii [Analogical Application of Criminal Law]. Pravo i zhizn' - Law and Life. 1924. Issue 1. Pp. 40-50. (In Russ.).

11. Lyublinskiy P. I. Tekhnika, tolkovanie i kazuistika Ugolovnogo kodeksa [Technique, Interpretation and Casuistry of the Criminal Code]. Petrograd, 1917. 267 p. (In Russ.).

12. Poznyshev S. V. Uchebnik ugolovnogo prava [Textbook on Criminal Law]. Moscow, 1923. 300 p. (In Russ.). 
13. Ponyatie analogii $v$ sovetskom ugolovnom prave i praktika ee primeneniya [The Notion of Analogy in Soviet Criminal Law and Practice of its Application]. Sovetskaya yustitsiya - Soviet Justice. 1939. Issue 3. Pp. 8-13. (In Russ.).

14. Pustoroslev P. P. Programma lektsiy po obshchey chasti russkogo ugolovnogo prava $s$ kratkim izlozheniem nekotorykh ponyatiy $i$ $o b$ "yasneniy [Lectures on the General Part of the Russian Criminal Law with Summary of Some Concepts and Explanations]. Yuriev, 1904. 425 p. (In Russ).

15. Rossiyskoe zakonodatel'stvo $X-X X$ vekov [Russian Legislation of the $10^{\text {th }}-20^{\text {th }}$ Centuries]. Moscow, 1988. Vol. 6. 432 p. (In Russ).

16. Svod zakonov Rossiyskoy imperii [Code of Laws of the Russian Empire]. St. Petersburg, 1912. Vol. 16. Part 1. 680 p. (In Russ).

17. Spasovich V.D. Uchebnik ugolovnogo prava [Textbook on Criminal Law]. St. Petersburg, 1863. Vol. 1. 428 p. (In Russ.).

18. Tagantsev N.S. Russkoe ugolovnoe pravo. Chast' obshchaya [Russian Criminal Law. General Part]. St. Petersburg, 1902. Vol. 1. 823 p. (In Russ.).

19. Shargorodskiy M. D. Analogiya v istorii ugolovnogo prava $i v$ sovetskom ugolovnom prave [Analogy in the History of Criminal Law and in Soviet Criminal Law]. Sotsialisticheskaya zakonnost' - Socialist Legality. 1938. Issue 7. Pp. 50-60. (In Russ.).

20. Ackermann B. Das Analogieverbot im Geltenden und Zukuenftigen Strafrecht. BreslauNeukirch, 1934. 50 p. (In Germ.).

21. Ehrlich E. Die Juristische Logik. Tuebingen, 1925. 337 p. (In Germ.).

22. Feuerbach P. J. A. Lehrbuch des Gemeinen in Deutschland Gueltigen Peinlichen Rechts. Giessen, 1847. 878 p. (In Germ.).

23. Glaser S. Nullum Crimen Sine Lege. Journal of Comparative Legislation and International Law. 1942. Vol. 24. Issue 1. Pp. 29-37. (In Eng.).

24. Hall J. Nulla Poena Sine Lege. The Yale Law Journal. 1937. Vol. 47. Issue 2. Pp. 165-193. (In Eng.).

25. Jhering $R$. Law as a Means to an End. Boston, 1913. 483 p. (In Eng.).

26. Kelsen H. Pure Theory of Law. Berkeley, 1970. 356 p. (In Eng.).

27. Krey V. Studien zum Gesetzesvorbehalt im Strafrecht: eine Einfuehrung in die Problematik des Analogieverbots. Berlin, 1977. $268 \mathrm{p}$. (In Germ.).

28. Lapenna I. The New Russian Criminal Code and Code of Criminal Procedure, I. The International and Comparative Law Quarterly. 1961. Vol. 10. Issue 3. Pp. 421-453. (In Eng.).
29. Locke J. Two Treatises of Government. London, 1821.405 p. (In Eng.).

30. Maris $C$. $W$. Milking the Meter - On analogy, Universalizability and World Views. Legal Knowledge and Analogy: Fragments of Legal Epistemology, Hermeneutics, and Linguistics; ed. by P. Nerhot. Dordrecht, 1991. Pp. 71-106. (In Eng.).

31. Mokhtar A. Nullum Crimen, Nulla Poena Sine Lege: Aspects and Prospects. Statute Law Review. 2005. Vol. 26. Issue 1. Pp. 41-55. (In Eng.). DOI: 1 0.1093/slr/hmi005.

32. Pound R. An Introduction to the Philosophy of Law. Clark, 2003. 306 p. (In Eng.).

33. Preuss L. Punishment by Analogy in National Socialist Penal Law. Journal of Criminal Law and Criminology. 1936. Vol. 26. Issue 6. Pp. 847-856. (In Eng.).

34. Priester J.-M. Zum Analogieverbot im Strafrecht. Juristische Methodenlehre und analytische Philosophie; Ed. by H.-J. Koch. Koenigstein im Taunus, 1976. Pp. 155-185. (In Germ.).

35. Rejewski E. Die Stellung des Strafrichters zur 'Schuldfrage' unter dem Gesichtswinkel der Abgrenzung der Ausdehnenden Auslegung zur Analogie. Breslau-Neukirch, $1937.71 \mathrm{p}$. (In Germ.).

36. Schreiber H-L. Gesetz und Richter. Zur geschichtlichen Entwicklung des Satzes nullum crimen, nulla poena sine lege. Frankfurt am Main, 1976. 265 p. (In Germ.).

37. The Use of Analogy in Criminal Law. Columbia Law Review. 1947. Vol. 47. Issue 4. Pp. 613-629. (In Eng.).

38. Vogenauer $S$. Die Auslegung von Gesetzen in England und auf dem Kontinent. B. I. Tuebingen, 2001. 663 p. (In Germ.).

39. Zippelius $R$. Juristische Methodenlehre: eine Einfuehrung. Muenchen, 1985. 112 p. (In Germ.).

\section{References in Russian}

1. Буцуковский Н. А. Очерк кассационного порядка отмены решений по судебным уставам 1864 года. СПб.: Тип. Второго Отделения Собствен. Е. И. В. Канцелярии, 1866. $181 \mathrm{c}$.

2. Градовский А. Д. О судебном толковании законов по русскому праву // Журнал гражданского и уголовного права. 1874. № 1. C. 1-62.

3. Дагель П. С. Об аналогии в советском уголовном праве // Российский криминологический взгляд. 2009. № 4. С. 82-86.

4. Дробышевский С. А., Тихонравов Е. Ю. Способы восполнения пробелов в праве. М.: Норма, 2014. 176 c. 
5. Дубровин Ф. П. О размерах допустимости аналогии при применении уголовного закона (окончание) // Журнал Министерства юстиции. 1899. № 6. С. 1-35.

6. Дурманов Н. Д. Понятие преступления. М.; Л.: АН СССР, 1948. 315 c.

7. Иоффе О. С. Ответственность по советскому гражданскому праву. Л.: Ленингр. ун-т, $1955.310 \mathrm{c}$.

8. К Казработке проекта общей части Уголовного кодекса СССР // Советская юстиция. 1938. № 20-21. C. 18-19.

9. Кауфман М. А. Пробелы в уголовном праве и способы их преодоления: автореф. дис. ... д-ра юрид. наук. М., 2009. 51 с.

10. Люблинский П. И. Применение уголовного закона по аналогии // Право и жизнь. 1924. № 1. С. 40-50.

11. Люблинский П. И. Техника, толкование и казуистика Уголовного кодекса: пособие к практическим занятиям по уголовному праву. Пг.: Тип. Романова, 1917. 267 с.

12. Познышев С. В. Учебник уголовного права. М.: Наркомюст, 1923. 300 c.

13. Понятие аналогии в советском уголовном праве и практика ее применения // Советская юстиция. 1939. № 3. С. 8-13.

14. Пусторослев П. П. Программа лекций по общей части русского уголовного права с кратким изложением некоторых понятий и объяснений. Юрьев: Тип. К. Маттисена, 1904. Вып. I. 425 с.

15. Российское законодательство $\mathrm{X}-\mathrm{XX}$ веков. М.: Юрид. лит., 1988. Т. 6. 432 с.

16. Свод законов Российской империи. СПб., 1912. Т. XVI, ч. 1.680 c.

17. Спасович В. Д. Учебник уголовного права. СПб.: Тип. Иосафата Огризко, 1863. Т. 1. $428 \mathrm{c}$.

18. Таганцев Н. С. Русское уголовное право. Часть общая. СПб., 1902. Т. I. 823 с.

19. Шаргородский М. Д. Аналогия в истории уголовного права и в советском уголовном праве // Социалистическая законность. 1938. № 7. C. 50-60.

20. Ackermann B. Das Analogieverbot im Geltenden und Zukuenftigen Strafrecht. BreslauNeukirch, 1934. $50 \mathrm{~s}$.

21. Ehrlich E. Die Juristische Logik. Tuebingen, 1925. $337 \mathrm{~s}$.

22. Feuerbach P. J. A. Lehrbuch des Gemeinen in Deutschland Gueltigen Peinlichen Rechts. Giessen, 1847. $878 \mathrm{~s}$.
23. Glaser S. Nullum Crimen Sine Lege // Journal of Comparative Legislation and International Law. 1942. Vol. 24, issue 1. Pp. 29-37.

24. Hall J. Nulla Poena Sine Lege // The Yale Law Journal. 1937. Vol. 47, issue. 2. Pp. 165-193.

25. Jhering R. Law as a Means to an End. Boston: The Boston Book Company, 1913. 483 p.

26. Kelsen H. Pure Theory of Law. Berkeley: University of California Press, 1970. 356 p.

27. Krey $V$. Studien zum Gesetzesvorbehalt im Strafrecht: eine Einfuehrung in die Problematik des Analogieverbots. Berlin, 1977. 268 p.

28. Lapenna I. The New Russian Criminal Code and Code of Criminal Procedure, I // The International and Comparative Law Quarterly. 1961. Vol. 10, issue 3. Pp. 421-453.

29. Locke J. Two Treatises of Government. London, $1821.405 \mathrm{p}$.

30. Maris $C$. $W$. Milking the Meter- On analogy, Universalizability and World Views. Legal Knowledge and Analogy: Fragments of Legal Epistemology, Hermeneutics, and Linguistics; ed. by P. Nerhot. Dordrecht, 1991. Pp. 71-106.

31. Mokhtar A. Nullum Crimen, Nulla Poena Sine Lege: Aspects and Prospects // Statute Law Review. 2005. Vol. 26, issue 1. Pp. 41-55. DOI: 1 0.1093/slr/hmi005.

32. Pound $R$. An Introduction to the Philosophy of Law. Clark, 2003. 306 p.

33. Preuss L. Punishment by Analogy in National Socialist Penal Law // Journal of Criminal Law and Criminology. 1936. Vol. 26, issue 6. Pp. 847-856.

34. Priester J.-M. Zum Analogieverbot im Strafrecht. Juristische Methodenlehre und analytische Philosophie; Hrsg. H.-J. Koch. Koenigstein im Taunus, 1976. S. 155-185.

35. Rejewski E. Die Stellung des Strafrichters zur 'Schuldfrage' unter dem Gesichtswinkel der Abgrenzung der Ausdehnenden Auslegung zur Analogie. Breslau-Neukirch, 1937. $71 \mathrm{~s}$.

36. Schreiber H.-L. Gesetz und Richter. Zur geschichtlichen Entwicklung des Satzes nullum crimen, nulla poena sine lege. Frankfurt am Main, 1976. $265 \mathrm{p}$.

37. The Use of Analogy in Criminal Law // Columbia Law Review. 1947. Vol. 47, issue 4. Pp. 613-629.

38. Vogenauer $S$. Die Auslegung von Gesetzen in England und auf dem Kontinent. B. I. Tuebingen, 2001. $663 \mathrm{~s}$.

39. Zippelius R. Juristische Methodenlehre: eine Einfuehrung. Muenchen, 1985. $112 \mathrm{~s}$. 